\title{
Proactive and Adaptive Decision Support Study (PDS)
}

\section{Status Report \#4}

Date of Report: 30 November 2014

For the Reporting Period: 1 Nov 2014-30 Nov 2014

Contract Number: N00014-14-P-1187

CDRL: B001

CLIN: 0005

Report Prepared For: Jeffrey Morrison, Code: 341

875 N. Randolph St.

Arlington, VA 22203-1995

703-696-2875

jeffrey.g.morrison@navy.mil

Report Prepared By:

Thomas G. Allen

Boston Fusion Corp.

1 Van de Graaff Drive, Suite 107

Burlington, MA 01803-5176

617-583-5730 x109

tom.allen@bostonfusion.com 


\section{Report Documentation Page}

Form Approved

OMB No. 0704-0188

Public reporting burden for the collection of information is estimated to average 1 hour per response, including the time for reviewing instructions, searching existing data sources, gathering and maintaining the data needed, and completing and reviewing the collection of information. Send comments regarding this burden estimate or any other aspect of this collection of information,

including suggestions for reducing this burden, to Washington Headquarters Services, Directorate for Information Operations and Reports, 1215 Jefferson Davis Highway, Suite 1204, Arlington

VA 22202-4302. Respondents should be aware that notwithstanding any other provision of law, no person shall be subject to a penalty for failing to comply with a collection of information if it

does not display a currently valid OMB control number.

1. REPORT DATE

30 NOV 2014

4. TITLE AND SUBTITLE

Proactive and Adaptive Decision Support Study (PDS)

6. $\operatorname{AUTHOR}(\mathrm{S})$

7. PERFORMING ORGANIZATION NAME(S) AND ADDRESS(ES)

Boston Fusion Corp.,,1 Van de Graaff Drive, Suite

107,,Burlington,,MA,01803

9. SPONSORING/MONITORING AGENCY NAME(S) AND ADDRESS(ES)

3. DATES COVERED

01-11-2014 to 30-11-2014

5a. CONTRACT NUMBER

5b. GRANT NUMBER

5c. PROGRAM ELEMENT NUMBER

5d. PROJECT NUMBER

5e. TASK NUMBER

5f. WORK UNIT NUMBER

8. PERFORMING ORGANIZATION

REPORT NUMBER

10. SPONSOR/MONITOR'S ACRONYM(S)

11. SPONSOR/MONITOR'S REPORT

$\operatorname{NUMBER}(S)$

12. DISTRIBUTION/AVAILABILITY STATEMENT

Approved for public release; distribution unlimited

13. SUPPLEMENTARY NOTES

14. ABSTRACT

15. SUBJECT TERMS

16. SECURITY CLASSIFICATION OF:

a. REPORT

unclassified b. ABSTRACT

unclassified c. THIS PAGE

unclassified
17. LIMITATION OF ABSTRACT

Same as

Report (SAR)
18. NUMBER 19a. NAME OF

OF PAGES RESPONSIBLE PERSON

4 


\section{Summary}

During November, the principal activities for Boston Fusion were related to development of the technical section of the InfoCog final report. Summaries of these activities appear in the subsequent section.

\section{Progress During Reporting Month}

During the month of November, Boston Fusion conducted the following activities for PDS:

- Continued development of a narrative describing the potential benefits of the Info-Cognitive Proactive Decision Support (InfoCog) technology.

- Continued development of a notional technology roadmap that describes the required technology necessary for InfoCog to become viable.

\section{Plans for Next Month}

During the month of December, we plan to do the following activities for PDS:

- Complete development of a narrative describing the potential benefits of the Info-Cognitive Proactive Decision Support (InfoCog) technology.

- Complete development of a notional technology roadmap that describes the required technology necessary for InfoCog to become viable.

- Refine workshop objectives. Complete technology space characterization to identify the needs and requirements for decision support technology for PADS, and describe how PDS technologies cover subsets of that space.

- Complete literature survey to identify relevant research communities and researchers that are exploring decision making from the analytical/mathematical point of view, based on our refined understanding of research objectives and potential transition opportunities. Based on survey, refine list of potential workshop participants and relevant topics for workshop sessions.

- Identify location and secure date for workshop, preferably in the DC area.

- Draft workshop invitation for review.

\section{Meetings and Teleconferences}

Table 1 reports meetings and teleconferences that Boston Fusion participated in during the reporting month in support of the PDS effort. 


\section{BOSTONFUSIEN}

Table 1. Significant meetings and conferences during current reporting period

\begin{tabular}{|l|l|l|l|}
\hline Date & Location & Participants & Purpose \\
\hline- & - & - & -
\end{tabular}

\section{Anticipated Problems}

No current problems.

\section{Financial}

Table 2. Project Financial Status

\begin{tabular}{l|l|l|l|l|}
$\begin{array}{l}\text { Current } \\
\text { Expenditures }\end{array}$ & $\begin{array}{l}\text { Cumulative } \\
\text { Expenditures }\end{array}$ & $\begin{array}{l}\text { Total Contract } \\
\text { Value }\end{array}$ & Funding & $\begin{array}{l}\text { Estimate to } \\
\text { Complete }\end{array}$ \\
\hline$\$ 3,998$ & $\$ 52,994$ & $\$ 149,988$ & $\$ 149,988$ & $\$ 96,994$ \\
\hline
\end{tabular}

Note: Financials are as of $10 / 26 / 14$. Financials for the month of November were not available by the due date of this report (12/1/14).

\section{Schedule of Deliverables}

Table 3. Project Deliverable Status

\begin{tabular}{|c|c|c|c|c|}
\hline CDRL & CLIN & Deliverable & Due Date & $\begin{array}{c}\text { Delivery } \\
\text { Date }\end{array}$ \\
\hline A001 & 0001 & PI Meeting Slides & $8 / 5 / 14$ & $7 / 30 / 14$ \\
\hline B001 & 0002 & Progress Report \#1 w/SF-298 & $8 / 31 / 14$ & $9 / 2 / 14$ \\
\hline B001 & 0003 & Progress Report \#2 w/SF-298 & $9 / 30 / 14$ & $9 / 30 / 14$ \\
\hline B001 & 0004 & Progress Report \#3 w/SF-298 & $10 / 31 / 14$ & $10 / 31 / 14$ \\
\hline B001 & 0005 & Progress Report \#4 w/SF-298 & $11 / 30 / 14$ & $12 / 1 / 14$ \\
\hline C001 & 0006 & Final Report and Briefing w/SF-298 & $12 / 31 / 14$ & \\
\hline & & & & \\
\hline
\end{tabular}

